\title{
CASE COMMENT - CUMBERLAND V ACCIDENT COMPENSATION CORPORATION
}

\author{
Anthea Williams*
}

In Cumberland $\mathrm{v}$ Accident Compensation Corporation, the Court of Appeal held that where a mother is denied the information that her foetus is disabled, and thus loses the opportunity to terminate the pregnancy, the "continuing pregnancy" can be a personal injury covered by the Accident Compensation scheme. This article examines the judgment and argues the Court of Appeal has extended New Zealand case law on "wrongful birth" without explicitly acknowledging this. The author suggests that, by focussing purely on the physical effects on the mother and her lost opportunity to determine the medical treatment given to her, the Court has avoided the value laden approach that has plagued other wrongful birth cases.

\section{INTRODUCTION}

Cumberland v Accident Compensation Corporation (Cumberland) ${ }^{1}$ is a recent "wrongful birth" case in which the Court of Appeal expanded the coverage of pregnancy under the statutory Accident Compensation scheme (the Scheme). ${ }^{2}$ In Cumberland, the treatment provider had failed to identify indications of spina bifida in a 20 -week foetus at an ultrasound, and so the case concerned the impact of the continuation of the pregnancy on the mother, rather than the conception itself. The Court held that the continuation of the pregnancy was a personal injury to the mother for which she had coverage under the Scheme. Although the Court viewed its decision as consistent with that of

* BA, LLB (Hons) (Victoria University of Wellington), LLM (Toronto), Barrister and Solicitor of the High Court. The views expressed are those of the author and not of her employer.

1 Cumberland v Accident Compensation Corporation [2013] NZCA 590, [2014] 2 NZLR 373 [Cumberland].

2 Definitions of the phrase "wrongful birth", and of "wrongful conception", vary. In this article, the term "wrongful birth" is used to describe cases taken by a parent alleging that, but for the negligence of a medical practitioner (for example, in performing a vasectomy or not advising of the potential for failure of a procedure), a (healthy) child would not have been conceived/born. The term "wrongful life" is generally used to describe a claim brought in the name of a child, who is generally disabled, that, but for the negligence of a medical practitioner, would not have been born. For further information, see Stephen Todd "Wrongful Conception, Wrongful Birth and Wrongful Life" (2005) 27 Syd LR 525 at 526. 
the Supreme Court in Allenby v Hannam (Allenby), ${ }^{3}$ a 2012 wrongful birth case, Cumberland represents an extension of Allenby and thus an extension of coverage for pregnancy under the Accident Compensation Act 2001 (the 2001 Act). ${ }^{4}$

This article summarises the issues, reasoning and conclusions of the Court in Cumberland and places the case in the context of New Zealand and overseas case law. It suggests that, by focussing purely on the physical effects on the mother and her lost opportunity to determine the medical treatment given to her, the Court has avoided the value laden approach that has plagued other wrongful birth cases.

\section{FACTS}

The appellant, Ms C, became pregnant and had a routine ultrasound scan 20 weeks into her pregnancy (the scan). No anatomical abnormality of the foetus was detected. ${ }^{5}$ However, at birth in May 2007, the baby was found to have spina bifida. The expert opinion was that the indications of this disease had been overlooked in the scan. In September 2007, the appellant made a claim to the Accident Compensation Corporation (the Corporation) for coverage for a treatment injury under the Act. ${ }^{6}$ She claimed the continuation of her pregnancy was a treatment injury because the incorrect diagnosis at the scan deprived her of the option of not continuing with the pregnancy. Ms $\mathrm{C}$ also filed a claim on behalf of the baby. The Corporation declined Ms C's claim, but, following application by Ms C, the Corporation's reviewer determined that Ms C had suffered a personal injury covered by the 2001 Act, relying on the High Court decision in Accident Compensation Corporation $v D(A C C \vee D)^{7}$ (examined briefly later).

The Corporation successfully appealed to the District Court, and the case proceeded as a case stated appeal on two questions of law to the High Court. Faire $\mathrm{J}$ answered the questions in favour of the Corporation, and the appellant was granted leave to appeal to the Court of Appeal on the following question: "Has the [appellant] suffered a personal injury under the Accident Compensation Act 2001?". The Court ultimately gave a provisional "yes", subject to remitting the case to the District Court on the factual issue of whether Ms C would have been able to obtain a termination after the scan.

3 Allenby v Hannam [2012] NZSC 33, [2012] 3 NZLR 425 [Allenby].

4 Originally called the Injury Prevention, Rehabilitation and Compensation Act 2001, but renamed in 2010.

5 An ultrasound scan at around 18-20 weeks of pregnancy is part of standard maternal care in New Zealand. A primary purpose of the scan is to examine for anatomical abnormalities in the foetus.

6 The Corporation is the Crown entity responsible for administering New Zealand's statutory universal nofault accidental injury scheme.

7 Accident Compensation Corporation v D [2007] NZAR 679 (HC) [ACC v D (HC)], appeal at [2008] NZCA $576[A C C \vee D(C A)]$. 
To aid in explaining the impact of the case, a short description of the legal background to wrongful birth cases in New Zealand is set out below.

\section{HISTORY OF WRONGFUL BIRTH CASES IN NEW ZEALAND}

Eligibility under the Scheme for coverage of "wrongful birth" or pregnancy in other situations has been affected by repeated changes to the governing legislation. ${ }^{8}$ The 1974 amendment to the original 1972 Act included as an eligible "personal injury by accident" any "medical misadventure". 9 This was taken to mean pregnancy resulting from a failed medical procedure, such as a failed sterilisation, could be covered. ${ }^{10}$ As well, pregnancy was specifically included as "actual bodily harm" that could occur from a sexual crime, and so a woman who became pregnant following a sexual assault would have coverage under the Scheme. ${ }^{11}$

The significant changes to the Scheme brought by the Accident Rehabilitation and Compensation Insurance Act 1992 were considered in case law to have removed coverage for pregnancy following medical misadventure ${ }^{12}$ (although the majority of the judges in Allenby later doubted the 1992 statute either intended to remove coverage for pregnancy or had indeed done so). ${ }^{13}$ The Corporation's position, as recorded in Allenby, is that after the 1992 changes, pregnancy following rape was also not covered but it would pay the costs of a termination in such a case, treating it as treatment for a "personal injury that is a mental injury" caused by a criminal act. ${ }^{14}$

The 2001 Act is widely regarded as returning the Scheme to more generous coverage, generally, and specifically in regard to medical cases. The "fault" requirement of "medical error" was removed and replaced by cover for personal injuries "caused by treatment". ${ }^{15}$ The claimants in Allenby and Cumberland sought coverage under the 2001 Act. The passage of other wrongful birth cases,

8 For more information on the case law and legislative changes, see Rosemary Tobin "Common Law Actions on the Margin" [2008] NZ L Rev 37 at 46-52.

9 Accident Compensation Act 1972, s 2(1) definition of "personal injury by accident", as amended by the Accident Compensation Amendment Act 1974, s 2(1).

10 Although in a dissent in the Court of Appeal decision of $L v M$ [1979] 2 NZLR 519 (CA) at 530, Cooke J (as he then was) doubted that such a medical misadventure would also amount to "personal injury", as it was medical misadventure for which the claimant was covered and the point was not decisively addressed.

11 Accident Compensation Act 1972, s 105B(1), inserted by the Accident Compensation Amendment Act 1974 , s 6 .

12 See Tobin, above $\mathrm{n} 8$, at 49 for a summary.

13 Allenby, above n 3, at [9] per Elias CJ, at [68] and [71] per Blanchard, McGrath and William Young JJ.

14 At [11], by reference to $\mathrm{s} 21$ of that Act.

15 Accident Compensation Act 2001, s 33. 
particularly Allenby, through the courts is highly relevant to the decisions in Cumberland and so these are briefly summarised below.

The Corporation's reviewer who allowed Ms C's claim had relied on the High Court decision of $A C C v D$ in which Mallon $\mathrm{J}$ held that pregnancy following a failed sterilisation could be a personal injury. ${ }^{16}$ Her Honour's decision was then overturned on appeal, the Court of Appeal declaring pregnancy was not a personal injury, ${ }^{17}$ and this was relied on by the District Court and High Court to find in favour of the Corporation in Cumberland. However, after this, the Supreme Court gave its decision in Allenby, which, as the Court acknowledged in Cumberland, "expanded the arguments available to the appellant". 18

Allenby concerned a claim for coverage under the 2001 Act by a plaintiff who became pregnant following a failed sterilisation. The Supreme Court overturned earlier case law to hold that pregnancy that results from a failed sterilisation has cover under the 2001 Act. Indeed, two of the three judgments considered that it was also covered under the 1992 Act. ${ }^{19}$ All judges agreed the pregnancy was a personal injury caused by medical error, as defined in s 26(1)(b) of the 2001 Act. Blanchard J (on behalf of McGrath and William Young JJ) and Tipping J held there was coverage as a medical misadventure under s 20(1)(b). ${ }^{20}$ The Chief Justice wrote separately to address why she considered cover was also available for the pregnancy under s 20(2)(g) of the 2001 Act (as a gradual process injury consequent on the personal injury of impregnation) and s 20(2)(f) (as a gradual process injury caused by medical misadventure). ${ }^{21}$

\section{REASONING IN CUMBERLAND}

In Cumberland, the Court adopted the approach of Blanchard $\mathrm{J}$ in Allenby and reviewed whether Ms C met all three requirements of s 20(1) of the 2001 Act: $^{22}$

- $\quad$ the claimant suffered personal injury in New Zealand on or after 1 April 2002 (not at issue in this appeal);

- $\quad$ the personal injury was any of the kinds of injuries described in s 26(1)(a),(b),(c) or (e); and

$16 A C C \vee D(\mathrm{HC})$, above $\mathrm{n}$ 7. For analysis of the High Court and Court of Appeal judgments, see Yasmin Moinfar "Pregnancy Following Failed Sterilisation under the Accident Compensation Scheme" (2009) 40 VUWLR 805 at 807-810 and 818-820.

$17 A C C \vee D(\mathrm{CA})$, above $\mathrm{n} 7$, at [54].

18 Cumberland, above n 1, at [13].

19 Allenby, above n 3, at [71] per Blanchard J, at [9] per Elias CJ.

20 At [76] per Blanchard J, at [95] per Tipping J.

21 At [30] and [31].

22 Cumberland, above n 1, at [32]. 
- $\quad$ the personal injury was described in any of the paragraphs in s 20(2).

\section{A Physical Injury of the Type Covered by the 2001 Act?}

Ms C argued that she had suffered a personal injury under s 26(1)(b), thus the issue, as framed by the Court of Appeal, was: ${ }^{23}$

... whether continuation of the pregnancy following the incorrect diagnosis and the consequential inability of the mother to implement her choice to terminate the pregnancy can constitute a physical injury suffered by the mother for the purpose of the definition of "personal injury".

The Court found that it was, adopting the view of Blanchard $\mathbf{J}$ in Allenby that the term "personal injury" is used in an expansive way in the 2001 Act and, by analogy with conception as a physical consequence of rape or following a failed sterilisation treatment, the continued pregnancy of the appellant following the misdiagnosed scan was capable of being a personal injury. ${ }^{24}$

In considering whether the continuing pregnancy was a personal injury, the Court emphasised that the focus must be the physical consequence to the appellant in the period after the misdiagnosis, namely the ongoing development of the foetus. The Court observed this consequence resulted in ongoing physical changes to the appellant, which, although part of a natural process, "cause discomfort and ultimately pain and suffering". ${ }^{25}$ They agreed with Blanchard $\mathrm{J}$ that an analogy could be made with an undetected tumour (which could be eligible for coverage if a treatment injury). ${ }^{26}$

In "belts and braces" reasoning, the Court of Appeal observed that the same result would occur if the Chief Justice's approach to physical injury in Allenby was applied; using a sprain or strain (which can be personal injuries) as comparators, the continuing pregnancy had a "profound impact", post-misdiagnosis, on the physiology of the appellant that constituted physical injury. ${ }^{27}$ The Court acknowledged that Ms C's situation differed from that of the claimant in Allenby, but considered there to be "no convincing reason", based on the text and purpose of the 2001 Act, to treat the ongoing physiological changes of a post 20 -week pregnancy, as being outside a "personal injury" under s $26 .^{28}$

\footnotetext{
23 At [34].

24 At [35].

25 At [36].

26 At [36] citing Allenby, above n 3, at [80].

27 Cumberland, above n 1, at [37].

28 At [38].
} 


\section{B Was There Treatment? And Did the Treatment Cause the Personal Injury?}

The last element to be met was whether Ms C had undergone "treatment" under the 2001 Act, which had caused the personal injury.

First, the Court was comfortable that the misdiagnosis of the scan was caused by a treatment, because it came within s 33(1)(b), (c) and (d) of the non-exhaustive statutory list of possible treatments; that is, it related both to the diagnosis she received, to the decision on treatment to be provided, and to a failure to provide further treatment, for example, additional scans or tests, in a timely manner. ${ }^{29}$

On the second issue, whether the personal injury was caused by the treatment, the uncontested evidence was that the claimant would have had the pregnancy terminated if she had been given the correct results of the scan. The Court discussed whether her loss of a chance to have a termination was sufficient causation or whether it was necessary to show on the balance of probabilities that she would have had an abortion. It adopted the latter approach, applying the Court of Appeal's decision in Accident Compensation Corporation v Ambros (Ambros) ${ }^{30}$ In Ambros, the Court considered a loss of a chance analysis would be incompatible with the Scheme, particularly in light of the changes to the statutory requirement for medical misadventure from "resulting from" to "caused by" in the 2001 Act.

In Cumberland, the Corporation relied on expert medical evidence to argue the Court could not assume a termination would have been legally open to the claimant after a scan done at the 20 week stage, as s 187A(3) Crimes Act 1961 sets out a more much more limited test for abortions after 20 weeks. The Court considered further evidence was required on this issue and referred the case back to the District Court for this factual matter to be determined. It made a provisional finding in favour of Ms $\mathrm{C}$ on the case stated question, holding that she was entitled to coverage under s 20(2)(b) (medical misadventure) and s 20(2)(f) (a gradual process injury).

There was no determination by the Court as to the appropriate scope of the claim, but the Court recorded the appellant's counsel's suggestion that it might include earnings-related compensation both in the short-term (including during pregnancy) and arguably beyond. ${ }^{31}$ The child's claim was dealt with separately by the Corporation and not addressed in the judgment.

29 Cumberland, above $\mathrm{n} 1$, at [43].

30 Accident Compensation Corporation v Ambros [2007] NZCA 304, [2008] 1 NZLR 340 as cited by Cumberland, above n 1, at [46]-[48].

31 Cumberland, above n 1, at [59]. 


\section{ANALYSIS}

The Court of Appeal in Cumberland was at pains to emphasise that its judgment was analogous with the Supreme Court's decision in Allenby. However, the Court's treatment of a "continuing pregnancy" extended the existing case law.

The reasoning of the majority of the Supreme Court in Allenby referred to the claimant "becoming" pregnant, with the impregnation being the result of the medical misadventure, and the pregnancy a continuation of the injury analogous to a disease or infection. For example, Blanchard $\mathbf{J}$ said: ${ }^{32}$

The development of the fetus following impregnation occurs because of the medical error, just as in the case of the undetected tumour. It causes significant physical changes to the woman's anatomy, which of course occur naturally but still cause discomfort and, at least ultimately, pain and suffering. If a disease or infection consequential on medical misadventure can be classified by the statute as a personal injury, it does not involve any greater stretching of language to similarly include a pregnancy which has the same cause.

The Chief Justice's conclusion does separate impregnation and a continuing pregnancy in her consideration of coverage for the injury, stating: ${ }^{33}$

A woman who becomes pregnant following a failed sterilisation suffers personal injury in the impregnation caused by medical misadventure within the cover provided by s 20(2)(b) and further personal injuries during the pregnancy "caused by a gradual process that is personal injury caused by medical misadventure" within the cover provided by s 20(2)(f)).

One possible way to read the Allenby and Cumberland decisions consistently is to view the personal injury of the plaintiff as "a state". For example, following the Allenby approach, a claimant who becomes pregnant following a failed sterilisation is eligible for coverage because she now has the personal injury of being pregnant, a state involving pain and discomfort she had wished to avoid. ${ }^{34}$ In the case of the injury of a "continuing pregnancy" as in Cumberland, the claimant was (presumably) prepared to be in the state of pregnancy, but not to be "pregnant with a foetus with spina bifida". The misdiagnosis has prevented the claimant from exercising her choice to obtain treatment to no longer be in this state. She is pregnant and does not know the foetus has spina bifida until the child is born. There is no evidence recorded in the Cumberland judgment that the physical

32 Allenby, above n 3, at [80] (emphasis added). See also [76] per Blanchard J.

33 Allenby, above n 3, at [31] (emphasis added).

34 This takes the case into the realm of personal choice and "autonomy": see Swati Jhaveri "Judicial Strategies in Recognising New Areas for Recovery in Negligence - Lessons Learned from Wrongful Conception Cases" (2013) 21 Tort L Rev 63 at 67. In New Zealand, the issue of whether the effect of pregnancy itself is a personal injury was determined by the Supreme Court in Allenby, above n 3. 
effects of the pregnancy or birth were greater or different for the mother because the foetus had spina bifida. Therefore, the physical injury that she suffers is, in one regard, the same, but the mother is in a state in which she does not wish to be. ${ }^{35}$ This is similar to dealing with the misdiagnosis as a legal wrong to the detriment of the patient's autonomy to determine her health treatment, but fits within the confines of a personal injury covered by the 2001 Act. $^{36}$

Perhaps the Court of Appeal has skirted over this issue and not highlighted the difference between the impregnation and a continuing pregnancy as a recognition of reproductive rights. For example, in Allenby, Tipping $\mathrm{J}$ recognised the right of a woman to choose whether to become pregnant and stated: "If she does not wish to do so, the consequences of her becoming pregnant are not to be discounted because pregnancy per se is a natural process." ${ }^{37}$ Perhaps underlying Cumberland is a recognition of the appellant's right to decide whether to continue with a pregnancy when correctly advised of the health of the foetus. The Court did recognise the claimant's decision must have been within the confines of New Zealand's abortion laws as it referred the case back to the District Court to determine whether the plaintiff, correctly advised, would have been legally able to access a termination. There is certainly no discussion in the judgment of "the blessing of a child", no comparison of raising a disabled child with a healthy child, and no use of the other value laden language that is so often a part of wrongful birth and wrongful life cases. ${ }^{38}$ This is a welcome approach to such cases.

The focus on the plaintiff's injury/state rather than "values" is perhaps helped by the Court in both Cumberland and Allenby dealing with the applicants' claim purely in the language of entitlement under the Scheme rather than looking to overseas case law. The overseas cases, working through these factual situations at the edges of existing tort law, have involved greater discussion of policy issues, although often by reference to "distributive justice" factors. This is despite the fact

35 Professor Todd has suggested that in a case where the parents themselves have decided to forgo their autonomy and have a child, but the child is born disabled, the defendant might be responsible for the disability costs, but not for any loss of autonomy: see Stephen Todd The Law of Torts in New Zealand (6th ed, Thomson Reuters, Wellington, 2013) at [6.9.04].

36 There is also the common law example of Rees v Darlington Memorial Hospital NHS Trust [2004] 1 AC 309 (HL) [Rees] where a disabled women had a child following a failed sterilisation. The majority of the House of Lords stated that the plaintiff's right to choose the way in which she lived had been invaded and for that legal wrong she was entitled to an award of damages. Rees has been criticised for creating a new head of damages in the law of damages: see for example Sandra Birgitta Elste "Analysis of Common Law Judgments in Regards of Wrongful Birth Cases" (4) New Zealand Postgraduate Law e-Journal 1 at 22-23.

37 Allenby, above n 3, at [89].

38 In the leading English wrongful birth case of McFarlane v Tayside Health Board [2000] 2 AC 59 (HL) at 96 and 113-114 respectively, Lord Millett said the birth of a child brought incalculable benefits to the parents and Lord Hope opined the birth of a child would always be a blessing. 
that in cases regarding the Scheme, courts do sometimes look to the common law to examine overseas developments, to the benefit of New Zealand law. ${ }^{39}$

There had been some overseas cases regarding "continuing pregnancies" although these have generally addressed claims for expenses/damages for the child rather than the issue of personal injury to the mother, and/or were brought by the disabled child (ie wrongful life claims). ${ }^{40}$ Whitehead $v$ Searle $^{41}$ arose from a similar fact situation to Cumberland, a child born with undetected spina bifida. However, it was ultimately determined as a claim by the father for damages against solicitors for their delay in prosecuting the mother's claim against the health provider prior to her death. Laws LJ (with whom Rimer LJ agreed) briefly examined what could have happened had the claim been brought by the father against the health authority, and said that recovery would turn on evidence as to whether the mother would have terminated her pregnancy if she had known of the foetus' defect. The judges indicated the mother could have sought damages for pain, suffering and loss of amenity, and the additional costs of raising a disabled child. ${ }^{42}$

\section{CONCLUSION}

Cumberland establishes that the continuation of a pregnancy may be a personal injury for which a claimant may receive coverage under the Scheme. The claimant will, of course, still have to establish that the personal injury was caused by a treatment injury for which there is coverage under the 2001 Act.

39 Professor McLay argues that there is particular benefit in looking at common law developments indicating the need for change or growth, particularly in areas at the margins of tort law such as wrongful birth cases: Geoff McLay "Accident Compensation - What's the Common Law Got to Do with It?" [2008] NZ L Rev 55 at 62. He suggests that the overseas case law assisted Mallon $\mathrm{J}$ in ACC $v D$ (HC), above $\mathrm{n}$ 7, at [55]-[56] to reach her conclusions about the coverage of pregnancy in the ACC scheme.

40 See for example, CES v Superclinics (Australia) Pty Ltd [1995] NSWSC 103 where the claimant sought damages in a negligence action alleging doctors had failed to diagnose her pregnancy. She claimed this had led to a "loss of opportunity" to terminate the pregnancy, and claimed damages for the pain and suffering of the pregnancy and birth, and for the economic loss of raising the child. The majority held she could not claim damages for the cost of raising her child as she had chosen not to adopt the child out at its birth, see Priestley J at [34] and Meagher JA at [11].

41 Whitehead v Searle [2008] EWCA Civ 285, [2009] 1 WLR 549.

42 At [2] and [19] per Laws LJ, and [70]-[72] and [78] per Rimer LJ. The position regarding wrongful births in England is that the mother of a child born following a failed sterilisation can claim general damages for the pain and suffering of pregnancy and childbirth and associated expenses but not child-raising: see for example McFarlane v Tayside Health Board, above n 3838. A gloss was placed on this in Rees, above n 36, awarding damages in recognition of the "legal wrong" done to the plaintiff, rather than for the costs of raising a child. Further, where a child is born disabled, the courts have allowed for expenses specifically related to that disability: Parkinson v St James Seacroft University Hospital Trust [2001] EWCA Civ 530, [2002] QB 266. The leading Australian case of Cattanach v Melchoir (2003) 215 CLR 1 (HCA) upheld the claim of parents for the costs of raising an unplanned child following a failed sterilisation. 
If the legislature disagrees with the outcomes of Allenby and Cumberland, it could respond by amending the legislation of the Scheme. Alternatively, if it agrees with eligibility in wrongful birth cases, it could make coverage of pregnancy (and the bounds of eligibility) explicit in the legislation. Associate Professor Rosemary Tobin has called for such statutory elaboration in order to act within the spirit of the Woodhouse Report, ${ }^{43}$ without doing violence to the definitions in the existing legislation. ${ }^{44}$ After all, some judges in the English and Australian cases have been clear that recovery for wrongful birth in tort law is, at its core, an issue of public policy. ${ }^{45}$ In response to the leading Australian wrongful birth case of Cattanach v Melchoir, ${ }^{46}$ Queensland (where the case originated) passed legislation limiting claimants' ability to recover common law damages in wrongful birth cases. ${ }^{47}$ Until then, the courts will continue to develop case law on the Scheme in a piecemeal fashion, adding the weight of case law on to an already unwieldy and incoherent statute.

43 New Zealand Royal Commission of Inquiry into Compensation for Personal Injury Compensation for Personal Injury in New Zealand (13 December 1967) [Woodhouse Report]. The Woodhouse Report, named for the chair, the Rt Hon Sir Owen Woodhouse, was set up to investigate complaints into New Zealand's then worker compensation scheme. It made recommendations that were the genesis for the introduction of the no-fault universal accidental injury scheme via the Accident Compensation Act 1972.

44 Tobin, above $\mathrm{n} 8$, at 53 .

45 See for example: Rees, above n 36, at [52]; Lord Steyn's comments in McFarlane v Tayside Health Board, above $\mathrm{n} 38$, at $81-83$ (although he denies his opinion is based on public policy factors); and the extensive discussion of the role of policy in such cases in Kirby J's decision in Cattanach v Melchoir, above n 42, at 49 and 52-54.

46 Cattanach v Melchoir, above $\mathrm{n} 42$.

47 Civil Liability Act 2003 (Qld), ss 49A and 49B. Similar provisions exist in New South Wales (Civil Liability Act 2002 (NSW), s 71) and South Australia (Civil Liability Act 1936 (SA), s 67), although these states provide specific exemptions for the additional costs arising where the child has a disability. 